Original research article

\title{
Evaluation of the self-directed learning readiness of different healthcare profession students in Turkey
}

\author{
Dilek Gürçayır ${ }^{1}{ }^{*}$, Yeşim Yaman Aktaş ${ }^{2}$, Esin Kavuran ${ }^{3}$, Neziha Karabulut ${ }^{1}$ \\ ${ }^{1}$ Atatürk University, Faculty of Nursing, Department of Surgical Nursing, Erzurum, Turkey \\ ${ }^{2}$ Giresun University, Faculty of Health Sciences, Department of Surgical Nursing, Giresun, Turkey \\ ${ }^{3}$ Atatürk University, Faculty of Nursing, Department of Fundamentals of Nursing, Erzurum, Turkey
}

\begin{abstract}
Objective: Self-learning is a process in which the initiative is on the individual and in which the individual determines his/her own learning necessities, aims and learning sources with or without the help of others. He/she also chooses appropriate learning strategies and evaluates learning results. This study was aimed at determining the self-directed learning readiness levels of students of nursing, midwifery and nutrition-dietetics.

Methods: The design of this study is descriptive. A total of 335 nursing, 171 midwifery, and 170 dietetic students participated in this study. This study was conducted at a local university in Turkey.

Results: In the study, more than half of the students (67.7\%) demonstrated a high level ( $>150)$ of SDLR. There were statistical differences between students' academic year, reading habits, and willingness to proceed to post-graduate training in the SDLR scores.

Conclusions: Our findings are encouraging and could help staff to assist students who require additional assistance to access strategies to develop the skills of self-management, desire for learning and self-control for use in an educational setting. Future research should address the facilitating factors for SDLR, barriers to SDLR and strategies to improve SDLR among health profession students.
\end{abstract}

Keywords: Healthcare students; Nursing students; Self-directed Learning Readiness (SDLR)

\section{Introduction}

Modern learning approaches increasingly have fewer structured learning activities and more self-directed learning tasks guided through consultation with academics (Stewart, 2007). In the past few decades, Self-directed learning (SDL) has focused more on nursing education and changes in development (Safavi et al., 2010). Self-directed learning (SDL) is one of the skills that students must obtain and adapt to lifelong learning throughout their career. Self-learning ensures that the learner has responsibility, manages learning without planning, and controls the supervisor until the evaluation process, determining learning skills and self-confidence (Alkan and Erdem, 2013; Aydede and Kesercioğlu, 2010). Self-learning readiness was defined as possession of the necessary attitude, talent and personal features for self-learning (Fisher et al., 2001). Having a high level of readiness level for self-learning, a student is aware of their responsibilities in learning and they act independently without any support. At the same time, they have confidence in learning so they can effectively use their time and have the ability to plan to finish their tasks and solve problems quickly and successfully in a short time (Abd-El-Fattah, 2010; Chou and Chen, 2008).
Nursing is a science that is changing rapidly and acquiring new knowledge is necessary. Because of this, training nurses who are still in academic life to be ready for SDL is important (Gyawali et al., 2011). Every student has a different level of motivation to learn. Students have diverse learning needs, and their attitudes and behaviors regarding learning and teaching vary. Moreover, every student responds differently to instructional practices and classroom environments. For teachers to fulfill the learning needs of all students and promote nursing education, they must first understand these diverse needs (Felder and Brent, 2005). Because of ongoing changes and complexities in the development of the nursing profession, nursing education has turned its focus to SDL (Safavi et al., 2010). To identify the various traits of students, teachers could assess variations in the students' levels of SDL readiness (SDLR). Understanding these traits could assist in significantly improving the educational skills and methods used in nursing education (Yuan et al., 2012). Nurses must follow the developments and changes in the area of health and hear about the innovations in order to utilize the knowledge and adapt themselves to these changes. They must have enough knowledge and equipment related to self-learning in order to develop their specifications during their professional education (Abd-El-Fattah 2010; Chou and Chen, 2008). The rapid

\footnotetext{
* Author for correspondence: Dilek Gürçayır, Atatürk University, Faculty of Nursing, Department of Surgical Nursing Atatürk University Campus, 25240 Yakutiye/Erzurum, Turkey; e-mail: dilekgurcayir@hotmail.com http://doi.org/10.32725/kont.2019.003 
changes in nursing have necessitated the application of new types of learning approaches. The aim of our study was to determine nursing students' readiness for self-directed learning in Turkey.

\section{Materials and methods}

The population of this descriptive research consisted of 676 students who studied at the Health Sciences Faculty of Atatürk University in the academic years 2014-2015. The research sample is made up of 676 volunteer students who were chosen with a non-probability sampling method. The aim of the study was explained to students and the data were gathered through face-to-face interview method. The average time for finishing the survey was 10 minutes. The study data were collected using an Information Form and Self-Directed Learning Readiness (SDLR) scale.

The Information Form, developed by the researchers, consisted of questions about the socio-demographic attributes of the participant, such as age, gender, year in school, type of high school graduated from, parental education, and place of residence.

Self-Directed Learning Readiness (SDLR) was developed by Fisher et al. (2001) and adapted for Turkish society by Kocaman et al. (2006). The SDLR scale has 40 items on a 5-point Likert scale, ranging from strongly disagree (1) to strongly agree (5) and has three subscales. Self-management (13 items) is about learning process activities, the desire for learning (12 items) is associated with taking responsibility for learning, and self-control (15 items) is related to control of the learning process. The scale score is between 40 and 200 points. Higher overall scores indicate greater levels of SDLR for self-directedness (Fisher et al., 2001). Fisher et al. reported high reliability for the scale in their study, and in our study the reliability value was 0.95 for the overall scale and 0.90 for the self-management subscale, 0.84 for the desire for learning subscale and 0.90 for the self-control subscale.

\section{Data analysis}

Statistical analyses were conducted with SPSS 22.0. Numbers, frequencies, independent t-test and ANOVA were used for statistical analysis of research data.

\section{Ethical considerations}

The compatibility of the study with ethical principles received written permission permission from the Ethics Committee of the Nursing Faculty of Atatürk University. The students involved in the research provided verbal permission about their willingness to participate. In the process of gathering data, questions from the students who agreed to participate were answered, and individual counselling was conducted according to the care required.

\section{Results}

A total of 335 nursing students (49.6\%), 171 midwifery students (25.3\%), and 170 dietetic students (25.1\%) participated in this study. The mean score of the students' age was $20.58 \pm$ 1.81. $82.1 \%$ of the students were female and $29.7 \%$ were firstyear students (Table 1 ).

Table 1. Demographic characteristics of students $(n=676)$

\begin{tabular}{|c|c|c|c|c|c|c|c|c|}
\hline & \multicolumn{2}{|c|}{ Nursing } & \multicolumn{2}{|c|}{ Midwifery } & \multicolumn{2}{|c|}{ Dietetics } & \multicolumn{2}{|c|}{ Total } \\
\hline & $n$ & $\%$ & $n$ & $\%$ & $n$ & $\%$ & $n$ & $\%$ \\
\hline \multicolumn{9}{|l|}{ Gender } \\
\hline Male & 81 & 24.2 & 0 & 0 & 39 & 22.9 & 121 & 17.9 \\
\hline Female & 254 & 75.8 & 171 & 100 & 131 & 77.1 & 555 & 82.1 \\
\hline \multicolumn{9}{|l|}{ Year of education } \\
\hline First & 95 & 28.4 & 61 & 35.7 & 45 & 26.5 & 201 & 29.7 \\
\hline Second & 80 & 23.9 & 38 & 22.2 & 40 & 23.5 & 158 & 23.4 \\
\hline Third & 80 & 23.9 & 32 & 18.7 & 43 & 25.3 & 155 & 22.9 \\
\hline Fourth & 80 & 23.9 & 40 & 23.4 & 42 & 24.7 & 162 & 24.0 \\
\hline \multicolumn{9}{|l|}{ Preference order of university entrance exam } \\
\hline 1st-5th choice & 240 & 71.6 & 72 & 42.1 & 82 & 48.2 & 394 & 58.2 \\
\hline 5th-10th choice & 56 & 16.7 & 44 & 25.7 & 36 & 21.2 & 136 & 20.1 \\
\hline 10th-15th choice & 27 & 8.1 & 33 & 19.3 & 26 & 15.3 & 86 & 12.8 \\
\hline 15th-24th choice & 12 & 3.6 & 22 & 12.9 & 26 & 15.3 & 60 & 8.9 \\
\hline \multicolumn{9}{|l|}{ Reasons for choosing nursing occupation ${ }^{1}$} \\
\hline Job opportunity & 224 & 66.9 & 90 & 52.6 & 70 & 41.2 & 384 & 56.9 \\
\hline Love of nursing & 92 & 27.5 & 66 & 37.5 & 56 & 32.9 & 214 & 31.7 \\
\hline To be beneficial to sick people & 99 & 29.6 & 42 & 24.6 & 26 & 15.3 & 167 & 24.8 \\
\hline Interest in the health field & 47 & 14.0 & 58 & 33.9 & 55 & 32.4 & 160 & 23.7 \\
\hline Family wish & 86 & 25.7 & 34 & 19.9 & 24 & 14.1 & 144 & 21.3 \\
\hline Because of the good salary & 74 & 22.1 & 25 & 14.6 & 20 & 11.8 & 119 & 17.7 \\
\hline Someone else's advice & 39 & 11.6 & 17 & 9.9 & 16 & 9.4 & 84 & 12.4 \\
\hline Because of the entrance score to the university & 24 & 7.2 & 11 & 6.4 & 30 & 17.6 & 65 & 9.7 \\
\hline \multicolumn{9}{|l|}{ Want post-graduate training } \\
\hline Yes & 226 & 67.5 & 78 & 45.6 & 127 & 74.7 & 431 & 63.8 \\
\hline No & 109 & 32.5 & 93 & 54.4 & 43 & 25.3 & 245 & 36.2 \\
\hline \multicolumn{9}{|l|}{ Having a computer } \\
\hline Yes & 212 & 63.3 & 98 & 57.3 & 124 & 72.9 & 434 & 64.2 \\
\hline No & 123 & 36.7 & 73 & 42.7 & 46 & 27.1 & 242 & 35.8 \\
\hline
\end{tabular}


Table 1. (Continued)

\begin{tabular}{|c|c|c|c|c|c|c|c|c|}
\hline & \multicolumn{2}{|c|}{ Nursing } & \multicolumn{2}{|c|}{ Midwifery } & \multicolumn{2}{|c|}{ Dietetics } & \multicolumn{2}{|c|}{ Total } \\
\hline & $n$ & $\%$ & $n$ & $\%$ & $n$ & $\%$ & $n$ & $\%$ \\
\hline \multicolumn{9}{|l|}{ Reasons for using a computer ${ }^{1}$} \\
\hline Investigate subject & 235 & 70.1 & 134 & 78.4 & 137 & 80.6 & 506 & 74.8 \\
\hline Social media & 139 & 41.5 & 75 & 43.9 & 78 & 45.9 & 292 & 43.1 \\
\hline Watching movies or series & 96 & 28.7 & 32 & 18.7 & 62 & 36.5 & 190 & 28.1 \\
\hline Learn about something & 71 & 21.2 & 42 & 24.6 & 23 & 13.5 & 136 & 20.1 \\
\hline Watching the news & 37 & 11.0 & 27 & 15.8 & 28 & 16.5 & 92 & 13.6 \\
\hline To play a game & 59 & 17.6 & 9 & 5.3 & 23 & 13.5 & 91 & 13.4 \\
\hline Listen to music & 41 & 12.2 & 20 & 11.7 & 16 & 9.4 & 77 & 11.3 \\
\hline \multicolumn{9}{|l|}{ Reading habits } \\
\hline Yes & 238 & 71.0 & 126 & 73.7 & 131 & 77.1 & 495 & 73.2 \\
\hline No & 97 & 29.0 & 45 & 26.3 & 39 & 22.9 & 181 & 26.8 \\
\hline \multicolumn{9}{|l|}{ Types of books read by students ${ }^{1}$} \\
\hline Science fiction & 121 & 36.1 & 56 & 32.7 & 85 & 50.0 & 262 & 38.7 \\
\hline Literature & 91 & 27.2 & 51 & 29.8 & 54 & 31.8 & 196 & 28.9 \\
\hline Entertainment & 75 & 22.4 & 49 & 28.7 & 42 & 24.7 & 166 & 24.5 \\
\hline Others & 70 & 20.9 & 29 & 17.0 & 23 & 13.5 & 122 & 18.0 \\
\hline Medicine and nursing & 50 & 14.9 & 31 & 18.1 & 34 & 20.0 & 115 & 17.0 \\
\hline Philosophy & 58 & 17.3 & 26 & 15.2 & 18 & 10.6 & 102 & 15.0 \\
\hline Culture-art & 49 & 14.6 & 25 & 14.6 & 25 & 14.7 & 99 & 14.6 \\
\hline Politics & 35 & 10.4 & 17 & 9.9 & 17 & 10.0 & 69 & 10.2 \\
\hline \multicolumn{9}{|c|}{ 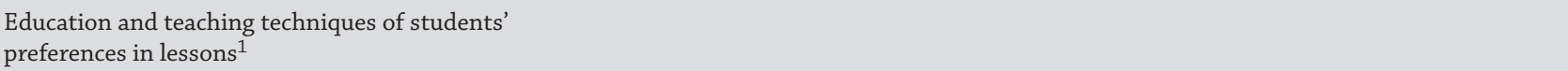 } \\
\hline Question-and-answer method & 183 & 54.6 & 113 & 66.1 & 97 & 57.1 & 393 & 57.1 \\
\hline Brainstorming & 172 & 51.3 & 84 & 49.1 & 93 & 54.7 & 349 & 51.6 \\
\hline Narration & 161 & 48.1 & 71 & 41.5 & 80 & 47.1 & 312 & 46.1 \\
\hline Case study & 152 & 45.4 & 68 & 39.8 & 80 & 47.1 & 300 & 44.3 \\
\hline Group discussion & 114 & 34.0 & 53 & 31.0 & 48 & 28.2 & 215 & 31.8 \\
\hline Role play & 39 & 11.6 & 20 & 11.7 & 18 & 10.6 & 77 & 11.3 \\
\hline Coaching method & 21 & 6.3 & 9 & 5.3 & 9 & 5.3 & 39 & 5.7 \\
\hline Demonstration & 16 & 4.8 & 5 & 2.9 & 5 & 2.9 & 26 & 3.8 \\
\hline Age $($ Mean + SD) & \multicolumn{2}{|c|}{$20.62 \pm 1.95$} & \multicolumn{2}{|c|}{$20.41 \pm 1.71$} & \multicolumn{2}{|c|}{$20.68 \pm 1.61$} & \multicolumn{2}{|c|}{$20.58 \pm 1.81$} \\
\hline
\end{tabular}

It was determined that $58.2 \%$ of the students chose their professions in the first five choices of the university examination. 56.9\% of the students chose their professions because of the job opportunities. More than half of the students (63.8\%) wanted to do post-graduate education, $64.2 \%$ of the students have a computer, and $74.8 \%$ of the students were using computers to investigate the subject. $73.2 \%$ of the students have a habit of reading books, and $38.7 \%$ of them read science-fiction type books. In their lessons, students most prefer the question and answer method (57.1\%) (Table 1).

In the study, more than half of the students $(67.7 \%)$ demonstrated a high level ( $>150)$ of SDLR (Chart 1$)$.

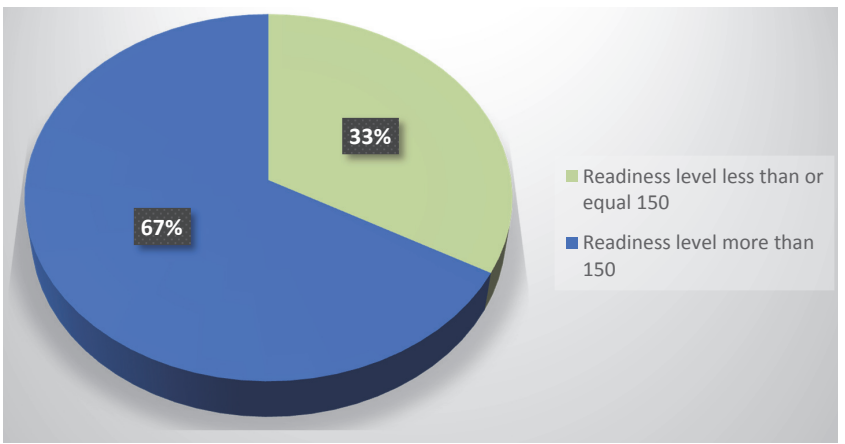

Chart 1. Students' level of readiness for self-directed learning
Table 2 shows a comparison of the overall mean score and the mean scores of the subscales of SDLR with the students' departments. The mean score of the self-management subscale was higher in the nursing students. The overall mean score and the mean score of the desire for learning subscale were higher in the midwifery students, but the results were not statistically significant ( $p>0.05)$.

Table 3 shows the comparison of the overall mean score of SDRL and the mean scores of the subscales of SDLR with the students' sociodemographic characteristics. The overall mean score of SDLR and the mean scores of the all subscales of SDRL were found to be higher in the female students, but the results were not statistically significant $(p>0.05)$. The mean score of the desire for learning subscale was significantly higher in the first-year students compared to those in the second, third and fourth year $(p<0.05)$. Also, the overall mean score of SDLR was significantly higher in the first-year students compared to the second and fourth-year students $(p<0.05)$. There was no significant difference between the other descriptive features of students and the overall mean score of SDLR and the mean scores of the subscales of SDRL.

According to the present study results, the overall mean score of SDRL and the mean scores of the subscales of SDLR were significantly higher in the students who want to do postgraduate training and in the students with reading habits ( $p=$ 0.000). 
Table 3. Comparison of scores of SDLR according to students' characteristics $(n=676)$

\begin{tabular}{lcccc} 
Student characteristics & Self-management & Desire for learning & Self-control & Overall score \\
\cline { 2 - 5 } & $($ Mean $+S D)$ & $($ Mean $+S D)$ & $($ Mean $+S D)$ & $($ Mean $+S D)$ \\
\hline Nursing & $48.09 \pm 9.11$ & $47.42 \pm 8.48$ & $59.34 \pm 10.54$ & $154.84 \pm 26.04$ \\
Midwifery & $47.82 \pm 8.61$ & $48.15 \pm 9.27$ & $59.20 \pm 9.78$ & $155.18 \pm 25.42$ \\
Dietetics & $46.57 \pm 9.63$ & $47.12 \pm 8.03$ & $59.99 \pm 9.28$ & $153.69 \pm 24.68$ \\
ANOVA, value & $F=1.601, p=0.202$ & $F=665, p=0.514$ & $F=317, p=0.728$ & $F=165, p=0.848$ \\
\hline
\end{tabular}

Table 3. Comparison of scores of SDLR according to students' characteristics $(n=676)$

\begin{tabular}{|c|c|c|c|c|}
\hline \multirow[t]{2}{*}{ Student characteristics } & Self-management & Desire for learning & Self-control & Overall score \\
\hline & $($ Mean $+S D)$ & $($ Mean + SD) & $($ Mean + SD) & $($ Mean + SD) \\
\hline \multicolumn{5}{|l|}{ Gender } \\
\hline Male & $46.53 \pm 9.35$ & $46.45 \pm 7.51$ & $58.25 \pm 10.17$ & $151.17 \pm 23.82$ \\
\hline Female & $47.88 \pm 9.07$ & $47.76 \pm 8.78$ & $59.73 \pm 10.17$ & $155.38 \pm 25.83$ \\
\hline \multirow[t]{2}{*}{ Independent $t$-test, $p$ value } & $t=1.472$ & $t=1.527$ & $t=1.462$ & $t=1.642$ \\
\hline & $P=0.142$ & $P=0.127$ & $P=0.144$ & $P=0.101$ \\
\hline \multicolumn{5}{|l|}{ Year of education } \\
\hline First & $48.54 \pm 9.00$ & $49.22 \pm 8.54$ & $60.91 \pm 10.33$ & $158.66 \pm 25.62$ \\
\hline Second & $47.25 \pm 8.54$ & $46.70 \pm 8.89$ & $58.92 \pm 9.19$ & $152.88 \pm 23.72$ \\
\hline Third & $48.11 \pm 9.47$ & $47.25 \pm 7.93$ & $59.35 \pm 10.12$ & $154.72 \pm 25.66$ \\
\hline Fourth & $46.44 \pm 9.43$ & $46.50 \pm 8.66$ & $58.34 \pm 10.26$ & $151.29 \pm 26.48$ \\
\hline \multirow[t]{2}{*}{ ANOVA, $p$ value } & $F=1.825$ & $F=4.000$ & $F=2.224$ & $F=2.862$ \\
\hline & $P=0.141$ & $P=0.008^{1}$ & $P=0.084$ & $P=0.036^{1}$ \\
\hline \multicolumn{5}{|l|}{ Want post-graduate training } \\
\hline Yes & $49.15 \pm 8.59$ & $48.61 \pm 7.83$ & $61.13 \pm 9.57$ & $158.89 \pm 23.75$ \\
\hline No & $44.99 \pm 9.45$ & $45.63 \pm 9.47$ & $56.54 \pm 10.18$ & $147.12 \pm 26.8$ \\
\hline \multirow[t]{2}{*}{ Independent $t$-test, $p$ value } & $t=5.829$ & $t=4.390$ & $t=5.847$ & $t=5.900$ \\
\hline & $P=0.000^{2}$ & $P=0.000^{2}$ & $P=0.000^{2}$ & $P=0.000^{1}$ \\
\hline \multicolumn{5}{|l|}{ Reading habits } \\
\hline Yes & $48.53 \pm 8.76$ & $48.35 \pm 8.41$ & $60.31 \pm 9.29$ & $157.19 \pm 24.21$ \\
\hline No & $45.21 \pm 9.68$ & $45.27 \pm 8.63$ & $57.17 \pm 11.54$ & $147.66 \pm 27.67$ \\
\hline \multirow[t]{2}{*}{ Independent $t$-test, $p$ value } & $t=4.232$ & $t=4.196$ & $t=3.629$ & $t=4.356$ \\
\hline & $P=0.000^{2}$ & $P=0.000^{2}$ & $P=0.000^{2}$ & $P=0.000^{2}$ \\
\hline
\end{tabular}

\section{Discussion}

Developing SDLR is a growing priority for health professional education, including nurses, midwives and dietetics. Therefore, it is very important to develop awareness to implement appropriate and effective strategies for SDL in university education that promotes lifelong learning (Cadorin et al., 2013). This study aimed to determine health profession students' readiness for self-directed learning.

In our study, the mean overall score of SDLR was 154.8, 155.1, and 153.6 for nursing, midwifery and dietetics, respectively. Studies that explore SDLR among nursing students show mixed results. These mean scores were lower than those of El-Gilany and Abusaad (2013). The authors reported the total mean scores of SDLR 159.6 among undergraduate nursing students at Al-Jouf University, Saudi Arabia. However, the findings are congruent with those of Yuan et al. (2012) who found that the mean overall score of SDLR was 154.72. Among Australian undergraduate nursing students the mean subscales of self-management, desire for learning and self-control were $44.26,47.31$ and 58.98 respectively, and the mean overall score of SDLR was 150.55 (Fisher et al., 2001).
The majority $(67.7 \%)$ of nursing students have a high level of SDLR (score $>150$ ). Generally, mean scores $>150$ indicate a high level of SDLR, while mean scores $\leq 150$ represent a low level of SDLR. This is in accordance with Abu-Moghli et al. (2005) and Safavi et al. (2010) who stated that the majority of Jordanian and Iranian nursing students had a high level of SDLR and perceived them as independent learners. However these results contradicted the study of Lestari and Widjajakusumah (2009) in Indonesia, which indicated that $50 \%$ of the students had low to moderate scores for SDLR. Shokar et al. (2002) reported that only $11 \%$ of students obtained self-directed learning readiness scores below the American standard score. Yuan et al. (2012) explored the SDLR of Chinese baccalaureate nursing students. With the exception of the self-control dimension, the overall scores and all subscale scores in our study were lower than theirs, implying weaker self-management abilities and desire for learning in baccalaureate nursing students in Fujian Province. Therefore, it would be essential for nursing faculties to use the effective teaching methods to improve these abilities.

The present study showed statistical significance among students based on their academic level, willingness to complete postgraduate education, and reading habits. Surprising- 
ly, first-year students scored higher in the subscale of desire for learning and in the overall score compared to other students. Our study is similar to that of Soliman and Al-Shaikh (2015), who found that first-year medical students in King Saud University (KSU) and Princess Nourahbint Abdulrahman had a higher level of SDLR scores. The results suggested that students were highly motivated for self-learning and had the ability for self-control. Similarly, Premkumar et al. (2014) reported a drop in the SDL skills in dental students over time. The authors examined the SDLR scores at the admission and at the end of each year at the University of Saskatchewan. Hence it is imperative to study the reasons for this drop in SDL skills in order to promote self-directed learning.

According to the study results, the overall scores and all subscale scores were higher in female nursing students, but the results were not statistically significant. Many learners' characteristics play a role in their level of SDLR. For instance, Karimi (2016) proposed that learner characteristics such as age, gender, and previous experience may act as either a facilitator or barrier to SDL. McCollin (2000) in the USA reported that gender was a factor affecting student-centered behavior. Among the Chinese baccalaureate nursing students, $62.3 \%$ reported a high level of SDLR with significant variation with gender (Yuan et al., 2012). However, our findings agree with those of Chen et al. (2006), and Roberson and Merriam (2005), who found that gender and age were not correlated with self-directed learning. Similarly, a descriptive correlational study on 81 medical and dentistry students reported that there was no demographic influence on SDLR (Nadi and Sadjadian, 2011). This variation indicates that the demographic factors may have different effects in diverse situations.

\section{Study limitations}

A limitation of the study is that due to its convenience sampling nature, the individuals who chose to participate may not be reflective of all health profession students; hence, the results cannot be generalized. Meanwhile, the SDLR scale is a self-reported measurement tool that may lead to the potential for bias.

\section{Conclusions}

In conclusion, this study showed high SDLR scores among all students. There were statistical differences between students' academic year in the total mean score of SDLR and the desire of learning subscale.

Enhancing SDL skills is a challenging mission for both faculty members and students. Awaiting the results of a national study, teachers of nursing students should assess and determine the appropriateness of SDL, irrespective of the learning style of students and their demographic characteristics. The successful introduction of self-directed learning into curricula requires both the preparation of students and staff to facilitate this type of learning. Our findings are encouraging and could help staff to assist students who require additional assistance to access strategies to develop skills of self-management, desire for learning and self-control for use in an educational setting. Future research should address the facilitating factors for SDLR, barriers to SDLR and strategies to improve SDLR among health profession students.

\section{Conflict of interests}

The authors have no conflict of interests to declare.

\section{Hodnocení samoregulované učební připravenosti studentů různých zdravotnických oborů v Turecku}

\section{Souhrn}

Cíl: Self-learning je proces, v němž je iniciativa zaměřena na jednotlivce a v němž jednotlivec určuje své učební potřeby, cíle a učební zdroje s druhými nebo bez jejich pomoci. Vybírá si také vhodné strategie učení a vyhodnocuje výsledky učení. Tato studie byla zaměřena na určení úrovně připravenosti samoregulovaného učení studentů ošetřovatelství, porodnictví a nutriční dietetiky. Metodika: Tato studie je popisná. Zúčastnilo se jí celkem 335 ošetřovatelů, 171 porodních asistentek a 170 studentů dietetiky. Tato studie byla provedena na místní univerzitě v Turecku.

Výsledky: Ve studii více než polovina studentů $(67,7 \%)$ prokázala vysokou úroveň (>150) samoregulační učební připravenosti. Byly zjištěny statistické rozdíly mezi akademickým rokem studentů, čtenářskými zvyklostmi a ochotou přistoupit k postgraduálnímu výcviku ve skóre samoregulační učební připravenosti.

Závěr: Naše zjištění jsou povzbudivá a mohou pomoci zaměstnancům pomáhat studentům, kteří potřebují dodatečnou pomoc v př́stupu ke strategiím pro rozvoj dovedností pro sebekontrolu, touhy po učení a sebeovládání ve vzdělávacím prostředí. Budoucí výzkum by se měl zabývat usnadňujícími faktory pro samoregulační učební připravenost, překážkami pro samoregulační učební připravenost a strategiemi pro zlepšení samoregulační učební připravenosti mezi studenty zdravotnických oborů.

Klíčová slova: samoregulační učební připravenost; studenti ošetřovatelství; studenti zdravotnických oborů

\section{References}

1. Abd-El-Fattah SM (2010). Garrison's model of self-directed learning: preliminary validation and relationship to academic achievement. Span J Psychol 13(2): 586-596. DOI: 10.1017/ S1138741600002262.

2. Abu-Moghli FA, Khalaf IA, Halabi JO, Wardam LA (2005). Jordanian baccalaureate nursing students' perception of their learning styles. Int Nurs Rev 52(1): 39-45. DOI: 10.1111/j.1466-7657.2004.00235.x.
3. Alkan F, Erdem E (2013). The effect of self-directed learning on the success, readiness, attitudes towards laboratory skills and anxiety in laboratory. $\mathrm{H} \mathrm{U}$ Journal of Education 44: 15-26.

4. Aydede MN, Kesercioğlu T (2010). The effect of active learning applications on students' critical thinking skills. Journal of Dokuz Eylul University Buca Education Faculty 27: 14-22.

5. Cadorin L, Bortoluzzi G, Palese A (2013). The self-rating scale of self-directed learning (SRSSDL): a factor analysis of the Italian version. Nurse Educ Today 33(12): 1511-1516. DOI: 10.1016/j. nedt.2013.04.010. 
6. Chen YF, Wang CM, Lin HJ (2006). Explore the relationships among demography, personality traits and self-directed learning. Journal of Human Resources and Adult Learning 2(2) 141-150.

7. Chou P, Chen W (2008). Exploratory study of the relationship between self-directed learning and academic performance in a web-based learning environment. Online Journal of Distance Learning Administration 11(1): 22-27.

8. El-Gilany A, Abusaad F (2013). Self-directed learning readiness and learning stylesamong Saudi undergraduate nursing students. Nurse Educ Today 33(9): 1040-1044. DOI: 10.1016/j. nedt.2012.05.003.

9. Felder RM, Brent R (2005). Understanding student differences. J Eng Educ 94 (1): 57-72. DOI: 10.1002/j.2168-9830.2005. tb00829.x.

10. Fisher M, King J, Tague J (2001). Development of a self-directed learning readiness scale for nursing education. Nurse Educ Today 21(7): 516-525. DOI: 10.1054/nedt.2001.0589.

11. Gyawali S, Jauhari AC, Shankar PR, Saha A, Ahmad M (2011). Readiness for self-directed learning among first semester students of a medical school in Nepal. J Clin Diagn Res 5(1): 20-23.

12. Karimi S (2016). Do learners' characteristics matter? An exploration of mobile-learning adoption in self-directed learning. Comput Hum Behav 63: 769-776. DOI: 10.1016/j. chb.2016.06.014.

13. Kocaman G, Dicle A, Üstün B, Çimen S (2006). Self-directed Learning Readiness Scale: Validity Reliability Study. 3. Active Education Congress Book. İzmir: Dokuz Eylul University, pp. 245-256.

14. Lestari E, Widjajakusumah D (2009). Students' self-directed learning readiness, perception toward student-centered learning and predisposition towards student centered behavior. South East Asian J Med Educ 3(1): 52-56.
15. McCollin E (2000). Faculty and student perceptions of teaching style: do teaching styles differ for traditional and nontraditional students? Bowling Green: Mid-South Educational Research Association.

16. Nadi MA, Sadjadian I (2011). Validation of a Self-directed Learning Readiness Scale for medical and dentistry students. Iranian J Med Educ 11(2): 174-182.

17. Premkumar K, Pahwa P, Banerjee A, Baptiste K, Bhatt $\mathrm{H}$, Lim HJ (2014). Changes in self-directed learning readiness in dental students: a mixed-methods study. J Dent Educ 78(6): 934-943.

18. Roberson DNJ, Merriam SB (2005). The self-directed learning process of older, rural adults. Adult Educ Q 55(4): 269-287. DOI: 10.1177/0741713605277372.

19. Safavi M, Schooshtari S, Mahmoodi M, Yarmohammadian MH (2010). Self-directed learning readiness and learning styles among nursing students of Isfahan University of Medical Sciences. Iranian J Med Educ 10(1): 27-36.

20. Shokar GS, Shokar NK, Romero CM, Bulik RJ (2002). Selfdirected learning: looking at outcomes with medical students. Fam Med 34(3): 197-200.

21. Soliman M, Al-Shaikh G (2015). Readiness for self-directed learning among first year Saudi medical students: a descriptive study. Pak J Med Sci 31(4): 799-802. DOI: 10.12669/ pjms.314.7057.

22. Stewart RA (2007). Investigating the link between selfdirected learning readiness and project-based learning outcomes: the case of international Masters students in an engineering management course. J Eng Educ 32: 453-465. DOI: $10.1080 / 03043790701337197$.

23. Yuan H, Williams BA, Fang JB, Pang D (2012). Chinese baccalaureate nursing students' readiness for self-directed learning. Nurse Educ Today 32(4): 427-431. DOI: 10.1016/j. nedt.2011.03.005. 